\title{
Guyana: the Lost Hadean crust of South America?
}

\author{
Guiana: a crosta Hadeana perdida da América do Sul?
}

\author{
Serge Nadeau ${ }^{1 *}$, Wei Chen ${ }^{2}$, Jimmy Reece ${ }^{1}$, Deokumar Lachhman ${ }^{1}$, \\ Randy Ault ${ }^{1}$, Maria Telma Lins Faraco ${ }^{3}$, Lêda Maria Fraga ${ }^{4}$, \\ Nelson Joaquim Reis ${ }^{5}$, Léandro Menezes Betiollo ${ }^{6}$
}

\begin{abstract}
A Hadean zircon xenocryst with a U-Pb zircon age of 4,219 $\pm 19 \mathrm{Ma}$, along with several zircon xenocrysts of Archean age (ca. 2,510 to $3,811 \mathrm{Ma}$ ) were found in a rock of the Paleoproterozoic Iwokrama Formation, which includes felsic volcanics and co-magmatic granitic intrusions. It demonstrates the existence of an underlying "Lost Hadean Crust", representing the oldest crustal component of the Guiana Shield. Detrital zircons of late Archean age, up to $2,700 \mathrm{Ma}$, are also present in the high-grade rocks of the Kanuku Complex, located to the south, and may be derived from the same Hadean-Archean crustal block.
\end{abstract}

KEYWORDS: Guyana; Hadean; Archean; zircon; U-Pb.
RESUMO: Um xenocristal de zircāo Hadeano com idade U-Pb de 4,219 $\pm 19 \mathrm{Ma}$, ao lado de muitos outros xenocristais de idade Arqueana (ca. 2,510 a 3,811 Ma) foi encontrado em rocha da Formação Iwokrama, de idade Paleoproterozóica, que inclui vulcânicas félsicas e intrusöes graniticas co-magmáticas. Ele demonstra a existência de uma subjacente "Crosta Hadeana Perdida" como componente crustal mais antiga do Escudo da Guianas. Zircóes detríticos de idade Arqueana tardia, até 2700 Ma, também estão presentes nas rochas de alto-grau do Complexo Kanuku, que ocorre mais a sul, e podem ser derivadas do mesmo bloco crustal Hadeano-Arqueano.

PALAVRAS-CHAVE: Guiana; Hadeana; Arqueana; zircão; U-Pb.

\section{INTRODUCTION}

During a joint geological and geodiversity mapping program performed by the geological surveys of Guyana and Brazil, ca. 95 rocks were collected in Guyana for petrographic, chemical and age dating studies along their common border, but these data will be presented elsewhere. Of these samples, 18 rocks taken from Southern Guyana were dated by Laser ICP-MS, and about 450 zircon U-Pb age determinations were made and are summarized here.

\section{GEOLOGY}

Guyana is part of the Guiana Shield that includes also rocks of Suriname and French Guiana and some areas of Colombia, Venezuela and Brazil (Gibbs \& Barron 1993). The oldest U-Pb ages of rocks in Guyana (ca. 2,000 - 2,245 Ma) occur in greenstone belts of the Barama-Mazaruni Supergroup in the northwestern part of the country (area 1 of Fig. 1 inset). In Southern Guyana, a limited number of rocks of the Iwokrama Formation and Southern Guyana Granite Complex have been dated more \footnotetext{
randy_ault07@yahoo.com

2State Key Laboratory of Mineral Deposit Research, Nanjing, China. E-mail:nmgchenwei@163.com

${ }^{3}$ Geological Survey of Brazil - CPRM-Belém, Brazil.E-mail: telma.faraco@cprm.gov.br

${ }^{4}$ Geological Survey of Brazil - CPRM-Rio de Janeiro, Brazil. E-mail: leda.fraga@cprm.gov.br

${ }^{5}$ Geological Survey of Brazil - CPRM-Manaus, Brazil.E-mail:nelson.reis@cprm.gov.br

${ }^{6}$ Geological Survey of Brazil - CPRM-Boa Vista, Brazil. E-mail: leandro.betiollo@cprm.gov.br

*Corresponding author

Manuscrito ID 30050. Recebido em: 25/10/2013. Aprovado em: 11/11/2013
}

${ }^{1}$ Guyana Geology and Mines Commission, Georgetown, Guyana.E-mail: goldenserge@hotmail.com; jimmy@ggmc.gov.gy; deokumarlachmann@yahoo.com; 
than 30 years ago by the Rb-Sr and K-Ar methods. A Rb-Sr age of 2,052 $\pm 50 \mathrm{Ma}$ and a $\mathrm{Nd}$ model age of 2,201 Ma were obtained for two granulite rocks of the Kanuku Complex (Gibbs \& Barron 1993). An old K-Ar age of 2,392 $447 \mathrm{Ma}$ (previously given at 2,595 $\pm 125 \mathrm{Ma}$ ) was also obtained in the Makarapan Granite Intrusion of southern Guyana (Berrangé 1977) but this K-Ar age has large uncertainty and needs further confirmation by $\mathrm{U}-\mathrm{Pb}$ dating.

The main geological and geochronological units in Guyana are shown in Fig.1 inset, as well as the location of the samples collected for age dating. Detailed geological descriptions of the main stratigraphic units of Guyana can be found in Gibbs and Barron (1993).

\section{METHODOLOGY}

Zircons were separated by using conventional magnetic and heavy liquid separation methods, and then handpicked under a binocular microscope. Grains were mounted in epoxy, and then polished for subsequent cathodoluminescence observation at the State Key Laboratory for Mineral Deposit Research, Nanjing, China. U-Th-Pb isotopes of zircon were analysed using an Agilent 7500 ICP-MS, coupled with a $213 \mathrm{~nm}$ wave-length laser microprobe also at the same laboratory. Detailed analytical procedures, precision and accuracy are described in Xu et al. (2012). For quality control, more than $135 \mathrm{U}-\mathrm{Pb}$ age determinations of zircon grains of standard GEMOC GJ-1 yielded a weighted average value of $608.3 \pm 5.2 \mathrm{Ma}$ (1 std., MSWD 0.79) which agrees with published results $(609.7 \pm 1.8 \mathrm{Ma}$ : Elhlou et al. 2007).

\section{RESULTS}

The dated rocks belong to the three main stratigraphic units present in Southern Guyana (Fig. 1). Histograms of zircon ages for each stratigraphic unit are shown in Fig. 2.

- The rocks of the Iwokrama Formation display the largest range of ages due to zircon xenocrysts. These rocks

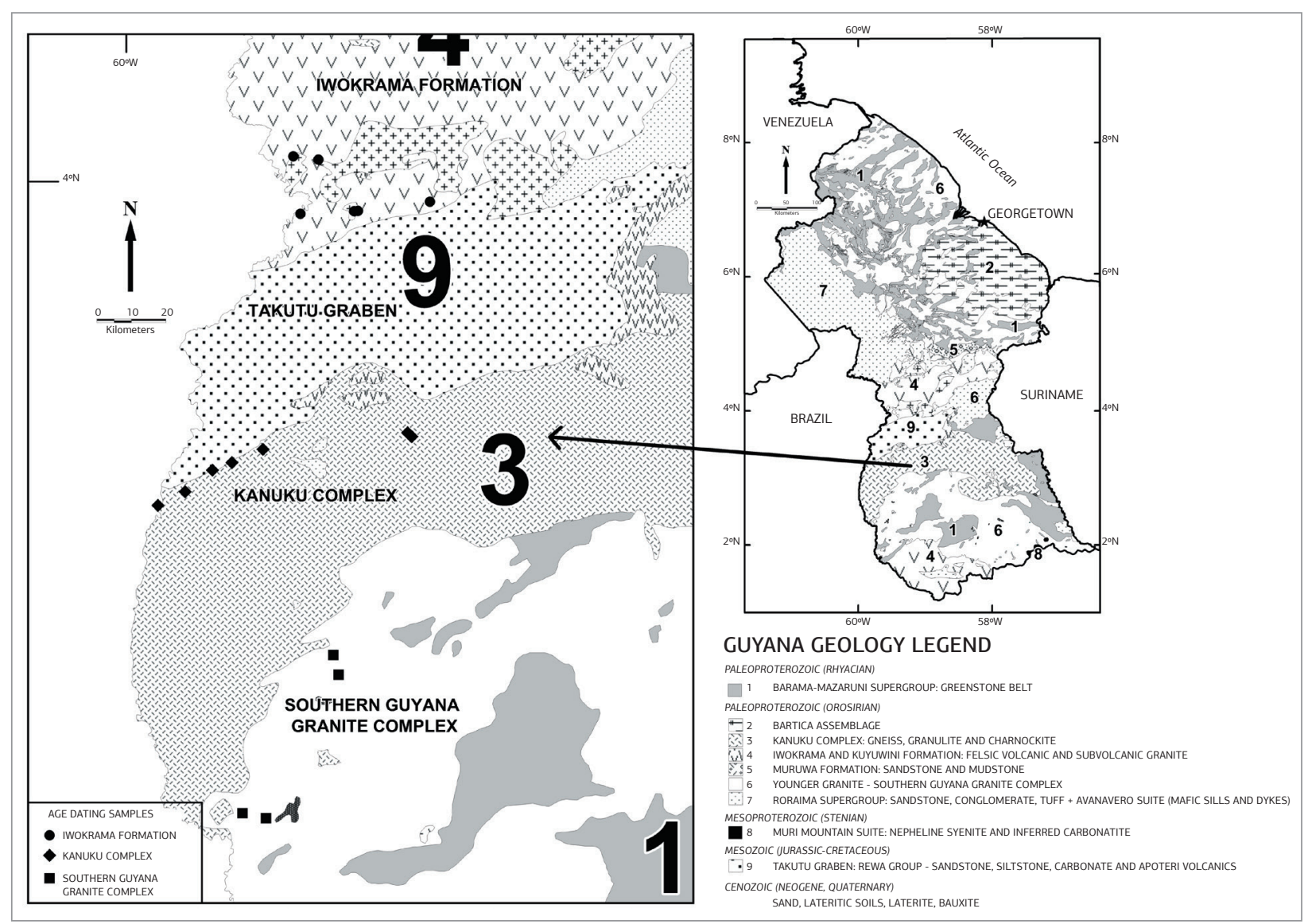

Figure 1. Location of samples collected for age dating in the Iwokrama Formation (black, dots), the Kanuku Complex (black, diamond shaped) and the Southern Guyana Granite Complex (black, squares).The inset shows a simplified geological map of Guyana including the main geological and geochronological units and their respective age periods (modified from Heesterman \& Nadeau, 2010). 
cluster at ca. 2,196 - 2,202 Ma, ca. 2,395 - 2,489 Ma, ca. 2,852 - 2,949 Ma, ca. 3,701 - 3,778 Ma and 4,219 \pm $19 \mathrm{Ma}$ (Fig. 2). The oldest value is from a zircon core with a concordant Hadean age 4,219 $\pm 19 \mathrm{Ma}$ (1 std., $100 \%$ concordant). A second zircon core age determination from the same crystal yielded a slightly discordant age of 4,210 Ma \pm 19 (1std.). The rim area of the same zircon gave a discordant age of $3,733 \pm 23 \mathrm{Ma}$. The crystallization age of the youngest zircon populations from the Iwokrama Formation (felsic volcanics and associated granite), that are $>95 \%$ concordant, range from 1,980 to $1,991 \mathrm{Ma}$. These ages are overlapping with the U-Pb zircon ages of $1,977 \pm 8 \mathrm{Ma}$ and 1,984 \pm 7 Ma measured by ion probe in two rocks of the Surumu Group in Brazil, considered to be correlative with the Iwokrama Formation (Reis et al. 2000).

- The metamorphic age of zircons from the Kanuku Complex is obtained from one S-type granite dated at 1,956 $\pm 10 \mathrm{Ma}$ and from paragneiss, migmatite and granulite samples ranging from $1,956 \pm 12 \mathrm{Ma}$ to 1,979 \pm 14 Ma. Moreover, several paragneiss samples contain significant proportions of detrital zircons with older age values clustering at ca. 2,200-2,269 Ma, ca. 2,450 - 2,520 Ma and ca. 2,635 - 2,721 Ma.

- The zircons of the granitic rocks of the Southern Guyana Granite Complex yielded ages between ca. 1,925 and $1,984 \mathrm{Ma}$. These rocks contain only a few older zircon xenocrysts clustering at ca. 2,086-2,138 Ma and ca. 2,261 - 2,297 Ma.

\section{DISCUSSION AND CONCLUSIONS}

The new $\mathrm{U}-\mathrm{Pb}$ zircon ages in rocks from Southern Guyana have implications in the understanding of the geological evolution of the Guiana Shield.

\section{Southern Guyana Granite Complex}

The ages ranging between 1,925 and 1,984 Ma determined for the Southern Guyana Granite Complex suggest that these rocks are post-Transamazonian (Main Transamazonian orogeny 2.08 - 2.26 Ma, De Avelar et al. 2003) and are not related to the group of Younger Granite intrusions of Transamazonian age that are present in northern Guyana as was previously concluded (Berrangé 1977: Gibbs \& Barron 1993). Some of the granitic intrusions of this complex could be correlated with rocks of the Rio Urubu Suite dated between 1,930 - 1,950 Ma and some intrusions from the Martins Pereira Suite in Brazil (Fraga et al. 1999 and references therein).

\section{Kanuku Complex}

The metamorphic ages between 1,956 and 1,979 Ma obtained in rocks of the Kanuku Complex overlap with the age range

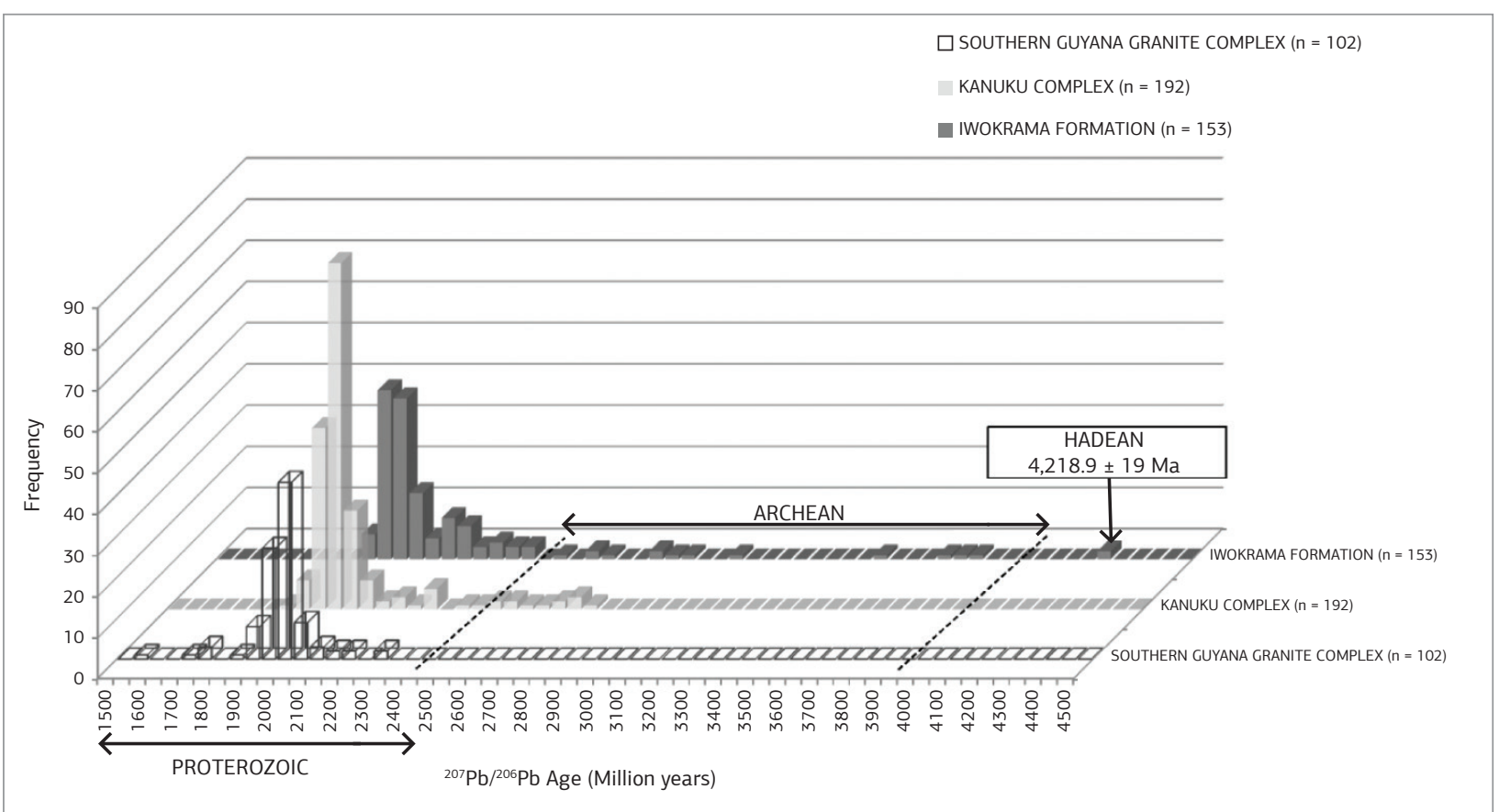

Figure 2. Histograms of U-Pb zircon age in rocks from the Southern Guyana Granite Complex (open pattern), the Kanuku Complex (pale grey pattern) and the Iwokrama Formation (dark grey pattern). More than $447 \mathrm{U}-\mathrm{Pb}$ age determinations of zircon core and rims are displayed. 
of ca. 1,969 to 1,995 Ma measured in rocks of the Cauarane Group present in Brazil, and therefore agreeing with their association to the ENE-WSW to NE-SW Cauarane-Coeroeni Belt proposed by Fraga et al. (2009) in Southern Guyana.

\section{Guiana Shield}

The zircon xenocrysts of Hadean and Archean ages ranging between 2,519 and 4,219 Ma, present in felsic magmatic rocks of the Iwokrama Formation dated at 1,981 to 1,990 Ma, suggest that they were derived from an older crustal component occurring underneath this tectonic unit. Fragments of this older crust were probably entrained and melted by the felsic magmas. However, the zircon crystals were preserved as they require much higher melting temperature $-1650^{\circ} \mathrm{C}$ than their host magmas (Trail et al. 2011). Therefore, most of the evidence of a Hadean to Archean reworked crust has been lost excepted for the presence of these zircon xenocrysts.

This Hadean to Archean crustal block could have been the source of detrital late Archean zircons, with ages up to about $2,800 \mathrm{Ma}(\mathrm{n}=10)$ found in the rocks of the Kanuku Complex located about $50 \mathrm{~km}$ to the south. Those Archean detrital zircons were probably derived from the erosion of the Hadean-Archean crustal block located to the north which later accumulated in a sedimentary basin that is now represented by the Kanuku rocks that were subsequently metamorphosed to granulite P-T conditions at ca. 1,956 - 1,979 Ma (Fig.1). Similarly, this crustal block could have been also the source of two Archean zircons found in sedimentary rocks of the Roraima Supergroup in Roraima State of northwestern Brazil, rather than being derived from the Imataca Complex in Venezuela about $650 \mathrm{~km}$ to the northwest (Santos et al. 2003).

This newly postulated location of an old HadeanArchean crustal block in Southern Guyana implies that the geological and tectonic evolution of the Guiana Shield and other Cratons in South America started more than $500 \mathrm{Ma}$ earlier than previously observed (ca. 3,400 Ma from the Amapá Complex of the Amazonian Craton and ca. 3,700 Ma in the São Francisco Craton: Cordani \& Sato 1999; de Avelar et al. 2003).

Lastly, this new Hadean locality in Guyana with an age of 4,219 $\pm 19 \mathrm{Ma}$ is one of the few sites which records the signature of the early Earth, with the oldest zircon age locality occurring in Australia (Jack Hills; age 4,404 Ma: Kemp et al. 2010) and slightly younger zircon age localities present in Canada (Acasta Gneiss at 4,203 Ma: Iizuka et al. 2006), China (4,100 Ma: Xu et al. 2012), and USA (Beartooth Mountains at 4,030 Ma: Maier et al. 2012).

\section{ACKNOWLEDGMENTS}

Special thanks to Prof. Xu Zhaowen of the State Key Laboratory of Mineral Deposit Research, University of Nanjing, Nanjing, China for allowing the free analysis of the zircons to S.N. The team of geologists from Guyana wants to acknowledge the Brazilian colleagues for their field guidance and warm hospitability while mapping in Brazil and Guyana. Thanks to A. Kemp for comments and suggestions to improve the manuscript.

\section{REFERENCES}

Berrangé J.P. 1977. The geology of Southern Guyana, South America. Institute of Geological Sciences Overseas Memoir. 4, p. 112.

Cordani U.G. \& Sato K. 1999. Crustal evolution of the South American Platform, based on $\mathrm{Nd}$ isotopic systematics on granitoid rocks. Episodes, 22:167-173.

De Avelar V.G., Lafon J.M., Delor C., Guerrot C., Lahondère, D. 2003. Archean crustal remnants in the easternmost part of the Guiana Shield: $\mathrm{Pb}-\mathrm{Pb}$ and $\mathrm{Sm}-\mathrm{Nd}$ geochronolgical evidence for Mesoarchean versus Neoarchean signatures. Géologie de la France, 2-3-4:83-99.

De Roever E.W.F., Lafon J.M., Delor C., Cocherie A., Rossi P., Guerrot C., Potrel A. 2003. The Bakhuis ultra-high-temperature granulite belt (Suriname): 1. Petrologicical and geochronological evidence for a counterclockwise P-T path at 2.07-2.05 Ga. Géologie de la France, 2-3-4:175-205.

Elhlou S., Belousova E., Griffin W.L. Pearson, N.J., O’Reilly S.Y. 2007 New Standard Reference Material for In-Situ U-Pb zircon dating. Agilent ICP-MS Journal, 32:4-5.
Fraga L.M.B., Araújo R.V. de, Haddad R.C. 1999. Suíte Metamórfica Rio Urubu. In: CPRM (ed.); Programa Levantamentos Geológicos Básicos do Brasil. Roraima Central, Folhas NA.20-X-B e NA.20-X-D (integrais), NA.20-X-A, NA.20-X-C, NA.21-V-A e NA.21-V-C (parciais). Escala 1:500.000. Estado de Roraima. Superintendência Regional de Manaus, Capítulo 3 - 3.5.

Fraga L.M., Reis N. J., Dall’Agnol R. 2009. Cauarane - Coeroeni BeltThe main tectonic feature of the Central Guyana Shield, Northern Amazonian Craton. Simpósio de Geologia da Amazônia, 11:02-05, Manaus, SBG.

Gibbs A.K. \& Barron C.N. 1993. The Geology of the Guiana Shield. Oxford Monograph on Geology and Geophysics No.23. ISBN 0-19-507350-9.

Heesterman L.H. \& Nadeau S. 2010. Geological map of Guyana at a scale of 1:1,000,000. Guyana, Geo-Services Department, Guyana Geology and Mines Commission p.1. 
Iizuka T., Horie K., Komiya T., Maruyama S., Hirata T., Hidaka H., Windley B.F. 2006. 4.2 Ga zircon xenocryst in an Acasta gneiss from northwestern Canada: Evidence for early continental crust. Geology, 34(4):245-248

Kemp A.I.S., Wilde S.A., Hawkesworth C.J., Coath C.D., Nemchin A., Pidgeon R.T., Vervoort J.D., DuFran, S.A. 2010. Hadean crustal evolution revisited: New constraints from $\mathrm{Pb}-\mathrm{Hf}$ isotope systematics of the Jack Hills zircons. Earth Planetary Sciences Letter, 296:45-56.

Maier A.C., Cates N.L., Trail D., Mojzsis S.J. 2012. Geology, age and field relations of Hadean zircon-bearing supracrustal rocks from Quad Creek, eastern Beartooth Mountains (Montana and Wyoming, USA). Chemical Geology, 312-313:47-57.

Nadeau S., Chen W., Reece J., Lachhman D., Ault R., Faraco M.T.L., Fraga L.M., Reis N.J., Betiollo L.M. 2013. Southern Guyana: The Lost Hadean Crust of South America? Goldschmidt Conference 2013 Abstract 1819
Reis N.J., Faria M.S.G. de Fraga L.M., Haddad R.C. 2000. Orosirian calc-alkaline volcanism and the Orocaima event in the northern Amazonian Craton, eastern Roraima State, Brazil. Revista Brasileira de Geociências, 30(3):380-383.

Santos J.O.S., Reis N.J., Chemale F., Hartmann L.A., Pinheiro S.S., McNaughton N.J. 2003. Paleoproterozoic evolution of northwestern Roraima state: Absence of Archean crust, based on $\mathrm{U}-\mathrm{Pb}$ and $\mathrm{Sm}-\mathrm{Nd}$ evidence. In: South-American Symposium on Isotope Geology, vol. 4, Salvador, Short papers, p. 278-281.

Trail D., Watson E.B., Tailby N.D. 2011. The oxidation state of Hadean magmas and implications for early Earth's atmosphere. Nature, 480:79-83.

Xu Y.J., Du Y.S., Huang H.W., Huang Z.Q., Hu L.S., Zhu Y.H., Yu W.C. 2012. Detrital zircon of $4.1 \mathrm{Ga}$ in South China. Chinese Science Bulletin, 57:4356-4362.

Arquivo digital disponível on-line no site www.sbgeo.org.br 
